\title{
FEED TRAINING OF PEACOCK BASS (Cichla sp.)
}

\author{
MOURA, M. A. M., ${ }^{1}$ KUBITZA, F. ${ }^{2}$ and CYRINO, J. E. P. ${ }^{3}$ \\ ${ }^{1}$ CPG (Ciência Animal e Pastagens), Escola Superior de Agricultura “Luiz de Queiroz”, USP, Avenida Pádua Dias, \\ 11, C.P. 9, CEP 13418-900, Piracicaba, SP, Brazil \\ ${ }^{2}$ Projeto Pacu, Rua 26 de Agosto, 1957, sala 2, Centro, CEP 79005-030, Campo Grande, MS, Brazil \\ ${ }^{3}$ Setor de Piscicultura, Departamento de Produção Animal, Escola Superior de Agricultura “Luiz de Queiroz", USP, \\ Avenida Pádua Dias, 11, C.P. 9, CEP 13418-900, Piracicaba, SP, Brazil \\ Correspondence to: Dr. José Eurico Possebon Cyrino, Setor de Piscicultura, Departamento de Produção Animal, \\ Escola Superior de Agricultura "Luiz de Queiroz", USP, Avenida Pádua Dias, 11, C.P. 9, CEP 13418-900, \\ Piracicaba, SP, Brazil, e-mail: jepcyrin@carpa.ciagri.usp.br \\ Received September 14, 1998 - Accepted June 23, 2000 - Distributed November 30, 2000
}

\begin{abstract}
The Amazonian cichlid peacock bass (Cichla sp.) is a highly marketable food and sport fish, therefore a suitable species for aquaculture. However, because of its piscivorous feeding preferences, the species does not accept dry feeds voluntarily, turning its intensive culture difficult and costly. This study aimed to wean fingerling peacock bass from inert moist food to dry diets. In a first experiment, 1,134 fingerlings weighting $0.27 \mathrm{~g}$ were divided in two $0.37 \mathrm{~m}^{3}$ hapas and fed ground fish flesh with $35 \%$ success. Then, $1.3 \mathrm{~g}$ fish were pooled, stocked in six $25 \mathrm{~L}$ cages and fed two pellet sequences with $80 \%, 60 \%$, $40 \%, 20 \%$ and $0 \%$ ground fish flesh (GFF). One sequence was flavored with $10 \%$ krill meal (Euphausia sp.). Training success of fish fed the GFF-00 diet flavored with krill reached $12 \%$ compared to $11.6 \%{ }^{\mathrm{a}}$ ( $\mathrm{p}<0.05$ ) for diets without krill meal. A second experiment was set up with 969, $1.5 \mathrm{~g}$ fish, trained with GFF with 39.8\% success. After the feed training period, $2.2 \mathrm{~g}$ fish were then fed a sequence of moist pellets containing $80 \%, 60 \%$ and $45 \%$ GFF. Fish trained to feed on moist pellets with $45 \%$ ground fish were pooled and stocked into nine $25 \mathrm{~L}$ cages. Fish were weaned to dry pellets without ground fish flesh (GFF-00) using three diet sequences: 1) dry pellets; 2) moist pellets; and 3) dry pellets flavored with $4 \%$ cod liver oil; all three diets contained 30, 10 and $0 \%$ GFF. The three sequences yielded, respectively $30.8 \%$ a, $23.6 \%^{\mathrm{a}}$, and $24.7 \%$ a $(\mathrm{p}<0.05)$ fish feeding on GFF-00. There were no apparent beneficial effects of increasing moisture or addition of cod liver oil as flavor enhancers in the weaning diets. This study revealed the feasibility of training peacock bass to accept dry pellets, but feeding young fish ground fish flesh seemed to be a major bottleneck in improving feed training success.
\end{abstract}

Key words: tucunaré, Cichla sp., feed training, palatability enhancers.

\section{RESUMO}

\section{Condicionamento alimentar do tucunaré Cichla sp.}

O ciclídeo amazônico tucunaré (Cichla sp.) tem atraído a atenção de técnicos e piscicultores porque é um peixe tanto esportivo como de mesa. Entretanto, devido ao hábito alimentar carnívoro, a espécie não aceita voluntariamente dietas secas, o que inviabiliza sua utilização em criação intensiva. O objetivo do presente estudo foi condicionar alevinos de tucunaré a ingerir dietas secas inertes, visando viabilizar sua utilização em piscicultura. Em um primeiro experimento, 1.134 alevinos com $0,27 \pm 0,1 \mathrm{~g}$ foram condicionados a ingerir filé de peixe moído (FP-100), obtendo-se um sucesso de condicionamento de $31,8 \%$. Esses peixes foram estocados em seis gaiolas de $25 \mathrm{~L}$ recebendo duas sequiências de dietas contendo $80 \%, 60 \%, 40 \%, 20 \%$ e $0 \%$ de filé de peixe, sendo uma delas flavorizada com $10 \%$ de farinha de krill (Euphausia sp.) (FK). Não foram observadas diferenças estatisticamente significativas entre os tratamentos. Em um segundo experimento, 969 peixes com 1,7 \pm 1,0 g foram condicionados a ingerir uma dieta inerte a partir de uma dieta inicial FP-100, conseguindo-se um sucesso de 39,8\%. 
Os peixes foram então condicionados a ingerir uma dieta FP-45 (37,2\% de sucesso) e novamente estocados em nove gaiolas de 25 L, recebendo dietas com FP-30, FP-10 e FP-00, testando-se o óleo de fígado de bacalhau e a umidade das dietas como palatabilizantes. A dieta seca sem palatabilizantes ofereceu maior porcentagem de condicionamento $(\mathrm{p}<0,05)$, mas não foram observadas diferenças estatisticamente significativas entre os três tratamentos, mesmo quando os ingredientes palatabilizantes foram retirados. Estes resultados permitem inferir que o tucunaré pode ser condicionado a ingerir dietas secas inertes, sem necessidade de inclusão de ingredientes palatabilizantes nas rações de condicionamento alimentar. Entretanto, condicionar os alevinos de tucunaré a ingerir o filé de peixe moído parece ser o principal entrave para aumentar o sucesso desta técnica.

Palavras-chave: tucunaré, Cichla sp., condicionamento alimentar.

\section{INTRODUCTION}

The objective of the present work was to develop feed training techniques and strategies for advanced peacock bass fingerlings (Cichla sp.), to facilitate the use of the species in intensive fish culture. Peacock bass are a multi-colored, lentic, carnivorous fish. They belong to the Cichlidae family and are indigenous to the Amazon Basin. Cichlids are the most frequently commercialized fish species in Manaus, and the peacock bass is the most explored fresh water species in that area. Because of the excellence of the flesh, it is considered a high quality edible fish. In addition, the species is rustic, prolific, performs effective parental care to fry and young fingerlings, has a fast growth rate, and has been successfully used in commercial sport fishing as well as to control prolific species in fish culture ponds and dams (Braga, 1982; Peixoto, 1982; Zaret, 1980; Santos, 1987; Saint-Paul, 1986; Perrone et al., 1993; Larsen, 1993).

Market demand for peacock bass stimulates its intensive, commercial production. Nevertheless, difficulties during rearing of fry and fingerling of the species still need to be overcome by fish farmers and technicians alike. The main obstacles to intensive commercial breeding of piscivorous fish is the cannibalism and the inability of fry and fingerlings to voluntarily accept formulated feeds. To overcome such a hurdle, feed training techniques have been developed (Kubitza, 1995a).

Factors such as initial weight and condition of the fish, water quality and temperature, food palatability, feeding schedule and diseases influence feed training success (McCraren, 1974; Kubitza, 1995a; Kubitza \& Lovshin, 1997a). The feed training of the piscivorous largemouth bass, the most popular fish in the United States sport fish industry, is a current practice, and illustrates the potential of feed training carnivorous species in general (Howick \& O'Brien, 1983). It is possible to produce up to $123 \mathrm{~kg} / \mathrm{ha}$ when largemouth bass is bred together with foraging fish (Sloane \& Lovshin, 1995). However, when trained to accept dry, pelletized commercial feeds and produced in ponds under intensive feeding practices, productivity of largemouth bass ranges from 2,700 to 7,281 kg/ ha in a 117 to 153 days growing period, with $82 \%$ survival and food conversion rate between 1.07 and 1.50 (Kubitza, 1995a; 1995b, Sloane \& Lovshin, 1995).

According to Kubitza (1995a), basic feed training strategies are: (1) direct transition, in which the natural food or starter feed is directly substituted by the final feed; (2) gradual feed transition, in which the starter feed or natural food is progressively substituted by the final feed until only the final feed is offered; and (3) gradual transition of feed ingredients (GTFI), in which the natural food is substituted by a sequence of feeds containing decreasing levels of the natural food. In GTFI, feed texture and flavor are gradually altered, and ingredients are adequately mixed, which avoids food selectivity and rejection compared to the other strategies (Kubitza, 1995a; Sloane \& Lovshin, 1995).

Kubitza \& Cyrino (1997) trained peacock bass to feed on pellets containing $10 \%$ ground fish flesh (GFF) using GTFI with $60 \%$ success. However, the authors were not able to train the peacock bass to accept dry pellets without fish flesh during the experimental period. In a second experiment, when the percent of GFF was reduced to $30 \%$, three flavor enhancers (meat and fish flavored dry commercial feed and fish flavored dry com- 
mercial feed plus $10 \%$ krill meal) were added $(10 \%)$ in order to increase diet acceptance and train fish to accept dry pellets without GFF (GFF-00). When percent GFF decreased to $10 \%$, the fish flavored feed plus $10 \%$ krill meal treatment yielded the best results $(81 \%$ feeders; $\mathrm{p}<0.05)$. However, it was not possible to train the peacock bass to feed on the GFF-00 during the experimental period.

The feed conditioning of carnivorous fish species aims to increase the feasibility, efficiency and profitability of carnivorous fish farming. The efficiency of conditioning can be estimated by the Retention of Feed Behavior (RTB), expressed as the percentage of the total number of feeders harvested in relation to the total number of fish stocked (Anderson, 1974). The development of novel techniques made possible, for instance, to increase the values of RTB of black bass from $40 \%$ in the 60's to $99.5 \%$ in the 90's (Snow, 1968; Anderson, 1974; Flickinger et al., 1975; Brandenburg et al., 1979; Williamson, 1981; Sloane \& Lovshin, 1995).

Formulated feeds for carnivorous species should be stable in water and still present texture, palatability and chemical compositions close to their preferred natural food (Lovell, 1989; Kubitza, 1995a; Kubitza \& Lovshin, 1997a). Fishery by-products currently utilized in feed conditioning of carnivorous species are whole or ground fish, fish meal, ground crustacean flesh, whole krill or krill meal. Even though it is not necessary anymore to train salmonids to accept commercial feed, whole krill or krill meal is still included in their diets to enhance feed palatability and increase appetite, leading to improved growth rates (Storebakken, 1998). Moist feed is more expensive, require refrigerated storage and are inadequate to be used in automatic feeders, but allow better survival rates and feed training success than dry feed. Therefore it is appropriately used during the culture of fry and fingerling of carnivorous fish (Lewis et al., 1969; Brandt et al., 1987; Kubitza, 1995a; Sloane \& Lovshin, 1995; Ono, 1996; Kubitza \& Lovshin, 1997b).

The ad libitum feeding or overfeeding is an usual practice in feed training programs. Cannibalism seems to be related more closely to food availability than to size variation between fish or stock density, justifying the use of overfeeding strategy (Anderson, 1974; McCraren, 1975; Brandenburg et al., 1979; Carmichael \& Williamson, 1986; Hecht \& Piennar, 1993; Kubitza, 1995a).

\section{MATERIAL AND METHODS}

In the first trial, two $0.37 \mathrm{~m}^{3}$ hapas were stocked with $567,0.27 \mathrm{~g}$ peacock bass each. During the nine day feed training period, each lot was fed four times a day (a) 100\% ground fish flesh (GFF100) or (b) $100 \%$ freeze dried krill (Euphausia sp.) (KM-100). Both diets were supplemented with $3 \mathrm{~g}$ of vitamin mixture, $1 \mathrm{~g}$ of mineral mixture and $0.5 \mathrm{~g}$ of vitamin $\mathrm{C} / \mathrm{kg}$. The percent of feeders was determined at days three, six and nine of the training period through visual observation of the ventral region of the fish. Feeders showed a distended abdomen, contrary to the emaciated aspect of nonfeeders. KM-100 treated fish which would not accept the starter diet, were fed the GFF-100 diet, aiming to yield the largest possible number of feeders to be used in the feed transition phase.

At day nine, fish trained to feed on GFF-100 (average weight $1.3 \mathrm{~g}$ ), were submitted to a 20 day feed transition period. The fish were pooled and stocked into six $25 \mathrm{~L}$ cages $(5 \mathrm{~mm}$ polyethylene mesh) at a density of 50 fish/cage, and then fed two sequences of diets containing decreasing levels of ground fish flesh $(60 \%, 40 \%, 20 \%$ and $0 \%$ GFF) for three days.

One of this sequences contained only ground fish flesh (GFF) while the other contained ground fish flesh plus $10 \%$ krill meal (GFF + KM10) (Table 1). Each sequence of diet was fed in triplicate. Ingredients were mixed and ground in an industrial meat mincer $(3 \mathrm{Hp})$ with a $1 \mathrm{~mm}$ diameter dial. At the end of the transition period fish were sampled to determine the percent of feeders.

For the second trial of the feed training phase, 969 peacock bass fingerlings, average weight $1.5 \mathrm{~g}$, were stocked into two $0.5 \mathrm{~m}^{3}$ cages, and fed for three days, four times a day, an starter inert diet consisting of $100 \%$ ground fish flesh (GFF-100) supplemented with vitamins, minerals and vitamin $\mathrm{C}$ as described above. Fish which accepted the GFF-100 diet, now with average live weight equal to $2.2 \mathrm{~g}$, were randomly stocked into two square, $65 \mathrm{~L}$ cages ( $5 \mathrm{~mm}$ polyethylene mesh) and submitted to a 16 day feed transition period.

They received a sequence of diets with decreasing levels of ground fish flesh, from $80 \%$ (GFF-80) to $45 \%$ fish flesh (GFF-45) (Table 2). Both cages were housed in $800 \mathrm{~L}$ cement tanks with constant, $5 \mathrm{~L} /$ minute water flow. 
TABLE 1

Training diets ${ }^{1}$ containing either fish flesh (FF) or krill meal (KM) for $1.3 \mathrm{~g}$ peacock bass weaned from moist diets with $80 \%$ FF (FF-80) or FF + KM (FF-80 + KM) to a dry diet without FF (FF-00).

\begin{tabular}{|c|c|c|c|c|c|c|c|c|c|c|}
\hline & $\begin{array}{c}\text { FF- } \\
80\end{array}$ & $\begin{array}{c}\text { FF- } \\
80+\text { KM }\end{array}$ & $\begin{array}{c}\text { FF- } \\
60\end{array}$ & $\begin{array}{c}\text { FF- } \\
60+K M\end{array}$ & $\begin{array}{l}\text { FF- } \\
40\end{array}$ & $\begin{array}{c}\text { FF- } \\
40+\text { KM }\end{array}$ & $\begin{array}{c}\text { FF- } \\
20\end{array}$ & $\begin{array}{c}\text { FF- } \\
20+K M\end{array}$ & $\begin{array}{c}\text { FF- } \\
00\end{array}$ & $\begin{array}{c}\text { FF- } \\
00+\text { KM }\end{array}$ \\
\hline Ingredients & \multicolumn{10}{|c|}{$\%$ inclusion } \\
\hline Fish flesh & 80 & 80 & 60 & 60 & 40 & 40 & 20 & 20 & - & - \\
\hline Fish meal & 20 & 10 & 40 & 30 & 60 & 50 & 80 & 70 & 80 & 70 \\
\hline Krill meal & - & 10 & - & 10 & - & 10 & - & 10 & - & 10 \\
\hline $\begin{array}{l}\text { Commercial } \\
\text { pellets }^{2}\end{array}$ & - & - & - & - & - & - & - & - & 20 & 20 \\
\hline Water & - & - & - & - & - & - & 15 & 20 & 35 & 35 \\
\hline $\begin{array}{l}\text { Vitamin } \\
\text { mixture }\end{array}$ & 0.3 & 0.3 & 0.3 & 0.3 & 0.3 & 0.3 & 0.3 & 0.3 & 0.3 & 0.3 \\
\hline $\begin{array}{l}\text { Mineral } \\
\text { mixture }\end{array}$ & 0.1 & 0.1 & 0.1 & 0.1 & 0.1 & 0.1 & 0.1 & 0.1 & 0.1 & 0.1 \\
\hline Ascorbic acid & 0.1 & 0.1 & 0.1 & 0.1 & 0.1 & 0.1 & 0.1 & 0.1 & 0.1 & 0.1 \\
\hline
\end{tabular}

1. Vitamin and mineral supplementation per $\mathrm{kg}$ of diet: vitamin A (36,000 UI), vitamin B6 (9 mg), vitamin D3 (4,500 $\mathrm{UI})$, vitamin E (150 UI), vitamin B12 (60 $\mu \mathrm{g})$, vitamin B1 (6 mg), vitamin B2 (6 mg), vitamin K3 (4.5 mg), folic acid (9 $\mathrm{mg})$, biotin $(0.6 \mathrm{mg})$, selenium $(0.45 \mathrm{mg})$, pantothenic acid $(30 \mathrm{mg})$, niacin $(90 \mathrm{mg})$, ascorbic acid $(1.0 \mathrm{~g})$; manganese $(0.04 \mathrm{~g})$, iron $(0.5 \mathrm{~g})$, zinc $(0.3 \mathrm{~g})$, cooper $(0.03 \mathrm{~g})$, cobalt $(0.003 \mathrm{~g})$, iodine $(0.0035 \mathrm{~g})$.

2. Commercial pellets: commercial diet for tropical fish unfit for packaging.

TABLE 2

Composition of transition $\operatorname{diets}^{1}(80 \%, 60 \%$ and $45 \%$ ground fish flesh) used to feed train peacock bass up to the day 16 of the experimental period.

\begin{tabular}{|l|c|c|c|}
\hline & GFF-80 & GFF-60 & GFF-45 \\
\hline Ingredients & \multicolumn{3}{|c|}{ \% Inclusion } \\
\hline Fish flesh & 80 & 60 & 45 \\
\hline Fish meal & 20 & 40 & 55 \\
\hline Vitamin mixture & 0.3 & 0.3 & 0.3 \\
\hline Mineral mixture & 0.1 & 0.1 & 0.1 \\
\hline Ascorbic acid & 0.1 & 0.1 & 0.1 \\
\hline
\end{tabular}

1. Vitamin and mineral supplementation per $\mathrm{kg}$ of diet: vitamin A (36,000 UI), vitamin B6 (9 mg), vitamin D3 (4,500 UI), vitamin E (150 UI), vitamin B12 (60 $\mu \mathrm{g})$, vitamin B1 $(6 \mathrm{mg})$, vitamin B2 $(6 \mathrm{mg})$, vitamin $\mathrm{K} 3(4.5 \mathrm{mg})$, folic acid $(9 \mathrm{mg})$, biotin $(0.6 \mathrm{mg})$, selenium $(0.45 \mathrm{mg})$, pantothenic acid $(30 \mathrm{mg})$, niacin $(90 \mathrm{mg})$, ascorbic acid $(1.0 \mathrm{~g})$; manganese $(0.04 \mathrm{~g})$, iron $(0.5 \mathrm{~g})$, zinc $(0.3 \mathrm{~g})$, cooper $(0.03 \mathrm{~g})$, cobalt $(0.003 \mathrm{~g})$, iodine $(0.0035 \mathrm{~g})$.

Next, 360 fish feeding on the GFF-45 diet, with an average weight of $3.3 \mathrm{~g}$, were randomly stocked into nine $25 \mathrm{~L}, 5 \mathrm{~mm}$ mesh net circular cages (40 fish/cage), distributed in three $800 \mathrm{~L}$ cement tanks. The peacock bass were then submitted to feed transition, where three types of diets were evaluated: (1) dry diet with ground fish flesh (DGFF); (2) moist diet with ground fish flesh (MGFF); and (3) dry diet with ground fish flesh plus cod liver oil
(DGFFO). By feeding on gradually small amounts of fish flesh in the diets, fish were conditioned to accept the GFF-00 diet (Table 3).

These diets differed also in regard to the inclusion of the flavor enhancers, moisture and cod liver oil, which were tested to demonstrate their efficiency in comparison to a standard diet without flavor enhancers (dry ground fish flesh diet DGFF). 
TABLE 3

Composition of transition diets ${ }^{1}(30 \%, 10 \%$ and $00 \%$ of ground fish flesh) used to wean peacock bass with or without taste enhancers.

\begin{tabular}{|l|c|c|c|c|c|c|c|c|c|c|}
\hline & \multicolumn{3}{|c|}{ Dry diet } & \multicolumn{3}{c|}{ Moist diet } & \multicolumn{3}{c|}{ Dry diet with oil } \\
\hline & \multicolumn{9}{|c|}{ Inclusion } \\
\hline Ingredients & GFFd-30 & GFFd-10 & $\begin{array}{c}\text { GFFd- } \\
\text { 00 }\end{array}$ & $\begin{array}{c}\text { GFFu- } \\
\mathbf{3 0}\end{array}$ & $\begin{array}{c}\text { GFu-10 } \\
\text { GFFu- } \\
\mathbf{0 0}\end{array}$ & $\begin{array}{c}\text { GFFo- } \\
\mathbf{3 0}\end{array}$ & $\begin{array}{c}\text { GFFo- } \\
\mathbf{1 0}\end{array}$ & $\begin{array}{c}\text { GFFo- } \\
\text { 00 }\end{array}$ \\
\hline Fish flesh & 30 & 10 & - & 30 & 10 & - & 30 & 10 & - \\
\hline Fish meal & 50 & 60 & 50 & 50 & 60 & 50 & 50 & 60 & 50 \\
\hline $\begin{array}{l}\text { Commercial } \\
\text { pellets }\end{array}$ & 20 & 30 & 50 & 20 & 30 & 50 & 20 & 30 & 50 \\
\hline Cod liver oil & - & - & - & - & - & - & 4 & 4 & 4 \\
\hline Water & 30 & 15 & 9 & 30 & 30 & 30 & 30 & 15 & 9 \\
\hline $\begin{array}{l}\text { Vitamin } \\
\text { mixture }\end{array}$ & 0.3 & 0.3 & 0.3 & 0.3 & 0.3 & 0.3 & 0.3 & 0.3 & 0.3 \\
\hline $\begin{array}{l}\text { Mineral } \\
\text { mixture }\end{array}$ & 0.1 & 0.1 & 0.1 & 0.1 & 0.1 & 0.1 & 0.1 & 0.1 & 0.1 \\
\hline Ascorbic acid & 0.1 & 0.1 & 0.1 & 0.1 & 0.1 & 0.1 & 0.1 & 0.1 & 0.1 \\
\hline
\end{tabular}

1. Vitamin and mineral supplementation per $\mathrm{kg}$ of diet: vitamin A (36.000 UI), vitamin B6 (9 mg), vitamin D3 (4,500 UI), vitamin E (150 UI), vitamin B12 (60 $\mu \mathrm{g})$, vitamin B1 (6 mg), vitamin B2 (6 mg), vitamin K3 (4.5 mg), folic acid (9 mg), biotin $(0.6 \mathrm{mg})$, selenium $(0.45 \mathrm{mg})$, pantothenic acid (30 mg), niacin (90 mg), ascorbic acid (1.0 $\mathrm{g})$; manganese $(0.04 \mathrm{~g})$, iron $(0.5 \mathrm{~g})$, zinc $(0.3 \mathrm{~g})$, cooper $(0.03 \mathrm{~g})$, cobalt $(0.003 \mathrm{~g})$, iodine $(0.0035 \mathrm{~g})$.

2. Commercial pellets: commercial diet for tropical fish unfit for packaging.

To validate the observations regarding the effects of the flavor enhancers on the acceptance of the diets, and the conditioning of fish to accept dry diets, similar to those available on the market for carnivorous species, all fish which accepted DGFF-00 received the DGFF-00 diet without flavor enhancers for an extra four-day period.

\section{Statistical Procedures}

The feed training phase of the first trial was analyzed by the use of a $\mathrm{X}^{2}$ test. Data from the feed transition period were submitted to ANOVA, and the treatment means were compared by Tukey test. The second trial was set up in randomized block design. Data were submitted to ANOVA, and treatment means were compared by Tukey test or general linear models - GLM (Snedecor \& Cochran, 1989; Steel \& Torrie, 1980).

\section{RESULTS}

Water temperature and dissolved oxygen were monitored daily at 0800 and 1700 using a digi- tal oxygen meter. Average values of dissolved oxygen and water temperature during the experimental period were, respectively: Trial $1-5.7 \mathrm{mg} / \mathrm{L}$ and $25.8 \mathrm{C}$ (morning); $9.3 \mathrm{mg} / \mathrm{L}$ and $27.7 \mathrm{C}$ (afternoon); Trial $2-4.4 \mathrm{mg} / \mathrm{L}$ and $24.3 \mathrm{C}$ (morning), $9.2 \mathrm{mg} / \mathrm{L}$ and 26.0 C (afternoon). These values range within the limits of tolerance for tropical species.

The results of the feed training period (Trial 1) are presented in Table 4. As survival rate in the first three days of the trial was about $50 \%$, it was decided that all fish would be fed GFF-100, what usually yields higher training success and survival rates.

For statistical analysis purposes, only the results of the first three days were used to compare the two treatments. The results of RFB for the feed transition period are presented in Table 5. Training and feed transition period results for the sequence of balanced diets with and without krill meal and decreasing levels of fish flesh are presented in Table 6.

Results referring to the feed training period of Trial 2 are presented in Table 7. 
TABLE 4

Training success ${ }^{1}$ of $0.27 \pm 0.1 \mathrm{~g}$ peacock bass receiving either moist (GFF-100) or dry (KM-100) diets.

\begin{tabular}{|c|c|c|c|}
\hline & \multicolumn{2}{|c|}{ \% Feeders } & \\
\hline & \multicolumn{2}{|c|}{ Initial diet } & KM-100 \\
\hline Days & GFF-100 & 11.1 & $<0.000$ \\
\hline 3 & 35.5 & 20.1 & $<0.049$ \\
\hline 6 & 32.3 & 19.2 & $<0.539$ \\
\hline
\end{tabular}

$\mathrm{X}^{2}$ test: day 3: 70,781; day 6: 3,865; day 9: 0,377.

1. Training success $=$ (number of feeders at end/number of fish in the beginning of experiment $) \times 100$.

2 . Because of high mortality rates, in the $3^{\text {rd }}$ day of feed training period all fish started receiving FF-100.

TABLE 5

Retention of feeding behavior ${ }^{1}$ (RFB) in regard to final mean weight (FMW) and weight gain ${ }^{2}$ (WG) of peacock bass (initial weight $=1.3 \pm 0.5 \mathrm{~g}$ ) weaning on a dry diet with or without krill meal*, up to $20^{\text {th }}$ day of the experimental period.

\begin{tabular}{|l|c|c|c|c|c|}
\hline & \multicolumn{3}{|c|}{ \% Fish flesh (day) } & & \\
\hline & $\mathbf{6 0}(\mathbf{8})$ & $\mathbf{2 0}(\mathbf{1 6})$ & $\mathbf{0 0}(\mathbf{2 0})$ & FMW (g) & WG (g/day) \\
\hline With krill & $93,3^{\mathbf{a}}$ & $93,3^{\text {a }}$ & $90,7^{\mathbf{a}}$ & $4,7 \pm 0,7^{\text {a }}$ & $0,17^{\text {a }}$ \\
\hline Without krill & $97,2^{\text {a }}$ & $95,0^{\text {a }}$ & $92,9^{\text {a }}$ & $4,1 \pm 0,5^{\text {a }}$ & $0,14^{\text {a }}$ \\
\hline
\end{tabular}

$1 . \mathrm{RFB}=$ (number of feeders at final harvest/total number of fish at final harvest) $\mathrm{x} 100$.

2 . Weight gain $=($ final mean weight - initial mean weight $) /$ number of days .

* Means followed by the same superscript letters do not differ significantly (Tukey, $\mathrm{p}<0.05$ ).

TABLE 6

Training sucess ${ }^{1}$ of peacock bass on feed training and during the training and feed transition* on Trial 1.

\begin{tabular}{|c|c|c|c|}
\hline & \multicolumn{3}{|c|}{ Diets } \\
\hline & GFF-100 & With krill & Without krill \\
\hline \% feeders & 31.8 & $12.0^{\mathrm{a}}$ & $11.6^{\mathrm{a}}$ \\
\hline
\end{tabular}

1. Training success $=$ (number of feeders at end/number of fish in the beginning of experiment $) \times 100$.

* Means followed by the same superscript letters do not differ significantly (Tukey, $\mathrm{p}<0.05$ ).

TABLE 7

Training sucess ${ }^{1}$ in regard to final mean weight (FMW) and weight gain $^{2}$ (WG) of 969 peacock bass (initial weight $=1.7 \pm 1.0 \mathrm{~g}$ ) trained on a moist FF-100 diet up to $5^{\text {th }}$ day of the experimental period.

\begin{tabular}{|c|c|c|c|}
\hline Initial diet & \% Feeders & FMW (g) & WG (g/day) \\
\hline GFF-100 & 39.8 & $2.0 \pm 1.2$ & 0.1 \\
\hline
\end{tabular}

1. Training success $=$ (number of feeders at end/number of fish in the beginning of experiment $) \times 100$.

2 . Weight gain $=($ final average weight - initial mean weight $) /$ number of days. 
Three hundred and eighty fish out of the 969 fish that began training, accepted the GFF-100 diet, reaching an average final weight of $2.0 \mathrm{~g}$. During the feed transition period, 360 fish from the three treatment groups, GFFd, GFFm and GFFo, reached the feeders stage $(93.3 \%$ of those that began transition from GFF-80 to GFF-45, and about $37 \%$ accumulated success since the beginning of training - Table 8). Table 9 presents data referring to the RFB related to the transition of the fingerlings from a $30 \%$ ground fish flesh diet to another containing $0 \%$ fish flesh. Training and feed transition period results for the sequence of balanced diets with or without flavor enhancers (moisture and code liver oil) are presented in Table 10. The percent of feeders was also calculated by observing the abdominal region, which appeared distended in feeders, contrary to the emaciated aspect of non-feeders.

TABLE 8

Retention of feeding behavior ${ }^{1}\left(\right.$ RFB) in regard to final mean weight (FMW) and weight gain $^{2}$ (WG) of peacock bass (initial weight $=2.0 \pm 1.2 \mathrm{~g}$ ) weaning on a moist $\mathrm{GFF}-45$, up to $12^{\text {th }}$ day of the experimental period.

\begin{tabular}{|c|c|c|c|}
\hline Initial diet & \% Feeders & FMW (g) & WG (g/day) \\
\hline GFF-80 & 93.3 & $3.2 \pm 1.4$ & 0.11 \\
\hline
\end{tabular}

1. RFB = (number of feeders at final harvest/total number of fish at final harvest) $\mathrm{x} 100$.

2. Weight gain $=($ final average weight - initial mean weight $) /$ number of days .

TABLE 9

Retention of feeding behavior ${ }^{1}$ (RFB) in regard to final mean weight (FMW) and weight gain ${ }^{2}$ (WG) of peacock bass (initial weight $=3.2 \pm 1.4 \mathrm{~g}$ ) weaning on GFF-30 dry diet (GFFd-30), GFF-30 moist diet (GFFm-30) and GFF-30 dry diet flavored with cod liver oil (GFFo-30), to a dry diets without fish flesh, with or without enhancers (GFF-00), using gradual transition of feed ingredients (GTFI), up to the day 16 of the experimental period.*

\begin{tabular}{|l|c|c|c|c|}
\hline & \multicolumn{2}{|c|}{ \% Feeders } & & \\
\hline \multicolumn{1}{|c|}{ Initial diet } & With enhancer & Without enhancer & FMW (g) & WG (g/day) \\
\hline GFFd-30 & $93.3^{\mathbf{a}}$ & $92.5^{\mathbf{a}}$ & $4.9 \pm 0.14^{\mathbf{a}}$ & $0.17^{\mathbf{a}}$ \\
\hline GFFm-30 & $86.7^{\mathbf{a b}}$ & $70.8^{\mathbf{a}}$ & $4.9 \pm 0.01^{\mathbf{a}}$ & $0.17^{\mathbf{a}}$ \\
\hline GFFo-30 & $74.2^{\mathbf{b}}$ & $74.2^{\mathbf{a}}$ & $4.6 \pm 0.25^{\mathbf{a}^{a}}$ & $0.14^{\mathbf{a}}$ \\
\hline
\end{tabular}

$1 . \mathrm{RFB}=$ (number of feeders at final harvest/total number of fish at final harvest) $\mathrm{x} 100$.

2. Weight gain $=($ final mean weight - initial mean weight $) /$ number of days.

* Means followed by the same superscript letters do not differ significantly (Tukey, $\mathrm{p}<0.05$ ).

TABLE 10

Training sucess ${ }^{1}$ of peacock bass on feed training and during the feed transition* on Trial 2.

\begin{tabular}{|l|c|c|c|c|}
\hline \multicolumn{1}{|c|}{ Diets sequence } & \multicolumn{4}{c|}{ \% Feeders } \\
\hline & GFF-100 & GFF-45 & Final diet in the transition & Final dry diet \\
\hline Dry diet & 39.8 & 37.2 & & $37.3^{\text {a }}$ \\
\hline Moist diet & & & $34.7^{\text {ab }}$ & $37.0^{\text {a }}$ \\
\hline Dry diet + cod liver oil & & & $29.7^{\mathbf{b}}$ & $28.3^{\text {a }}$ \\
\hline
\end{tabular}

1. Training success $=$ (number of feeders at end/number of fish in the beginning of experiment $) \times 100$.

* Means followed by the same superscript letters do not differ significantly (Tukey, $\mathrm{p}<0.05$ ). 


\section{DISCUSSION}

Researchers have long speculated about the effects of flavor enhancers in feed conditioning diets. Lovshin \& Rushing (1989) used an amino acid mixture in semi-moist diets (Biodiet ${ }^{\mathrm{TM}}$ ) for black bass. The results demonstrated that this flavor additive had little influence on fish training, compared to diets without the additive $(90.6 \%$ feeders) or even moist ground fish flesh diets $(95.6 \%$ feeders).

Data obtained in this study show that the use of taste enhancers like krill meal, cod liver oil and greater moisture content do not improve peacock bass feed training success. Fish immediately accepted the starter GFF-100 diet (35,5\% success), but the KM-100 diet was rejected (only $11 \%$ of feeders). It was necessary to substitute the KM100 diet by GFF-100 during the feed training period. These results are inferior to those obtained by Kubitza \& Cyrino (1997) for the peacock bass (76\%). Krill meal floats on the water surface, while the ground fish flesh sinks below water level. This factor seemed to be decisive in the capture of feed by the species, which usually forages below the water surface. The same behavioral pattern was observed by Kubitza (1995b) for black bass, which immediately accepted a $100 \%$ ground fish flesh diet, but demanded several attempts to start accepting a $100 \%$ freeze dried krill diet.

Kubitza (1995b) and Kubitza \& Lovshin (1997b) demonstrated that a starter diet with fish flesh without taste enhancers allowed better training success for black bass, resulting in almost $75 \%$ feeders on a final dry, salmonids diet in comparison to $41 \%$ training success yielded by the use of a starter diet of freeze dried krill. In addition, fish fed ground fish flesh as starter diet had greater weight gain (44 mg/day) than fish that received freeze dried krill as starter diet ( $24 \mathrm{mg}$ /day).

A serious limitation to feed training peacock bass seems to be the weight of the fish at the beginning of feed training. In the first experiment, only $31.8 \%$ of the fish accepted the starter inert diet - GFF-100. Fish used in this experiment had an initial weight of $0.27 \mathrm{~g}$, and almost $50 \%$ of the lot died in the first three days of the experimental period. In the second experiment, the initial weight of peacock bass was $1.5 \mathrm{~g}$, and percent success of feed training was $39.8 \%$.
Kubitza (1995a) and Kubitza \& Lovshin (1997b) tested the effect of initial fish weight on the feed training success of black bass receiving freeze dried krill as starter diet. Those authors observed an increase from $7 \%$ to $52 \%$ of fish feeding on a final dry diet when the initial fish weight went from 0.2 to $1.4 \mathrm{~g}(\mathrm{p}<0.01)$. When the starter diet contained ground fish flesh, the percent of fish feeding on a final dry diet went from $59 \%$ to $88 \%$, accompanying the increase in the initial weight from 0.6 to $1.4 \mathrm{~g}$ ( $\mathrm{p}<0.01)$. When the starter diet was ground fish flesh, the success of feed training was $75 \%$, and when freeze dried krill was used it was about $41 \%$, with fish weight ranging from 0.6 to $1.4 \mathrm{~g}$.

Unsuccessfull attempts to feed train carnivorous fish are credited to high mortality by starvation. Fish that begin feed training with a larger initial size and does not feed during the first training period, still has organic reserves at the end of this first training session, and that gives them a second chance to learn to accept the inert food (Flickinger et al., 1975; Williamson, 1981; Willis \& Flickinger, 1981). The best success rates on feed training black bass are attained with fingerlings with an average initial weight between $0.5 \mathrm{~g}$ and $0.9 \mathrm{~g}$. It seems that these fish have enough energy reserves to survive until they learn to feed on the inert diet (Williamson, 1981; Kubitza, 1995b; Sloane \& Lovshin, 1995; Kubitza \& Lovshin, 1997a). Therefore, it is suggested that the average initial weight to submit black bass to feed conditioning should be approximately $0.9 \mathrm{~g}$. Regarding peacock bass, we observed a larger percentage of fish feeding on the final dry diet $(31.6 \%)$ when the average initial weight was $1.5 \mathrm{~g}$, compared to those that began training with an average weight of $0.27 \mathrm{~g}$ $(11.8 \%)$.

In opposition to what has been observed for black bass (Kubitza, 1995b; Kubitza \& Lovshin, 1997a), walleyes Stizostedion vitreum (Rottiers \& Lemm, 1985), and salmonids (Storebakken, 1998), it was observed that neither feed conditioning nor the weight gain of peacock bass is improved by the use of krill meal in the training diets, and also as compared to diets without feed enhancers (12\% and $11.6 \%$, respectively). However, results herein obtained were similar to those for the lake sturgeon (Acipenser fulvescens), which showed a decrease on food intake and, consequen- 
tly, loss of weight when krill was added to the species diet (Moreau \& Dabrowski, 1996).

The values of RFB observed for the peacock bass in this experiments, when the fish were submitted to a gradual feed ingredient transition without addition of enhancers in the pellets, averaged $92.9 \%$ and were not significantly different from the values obtained for the feed transition which used krill as enhancer $(90.7 \%)$. These results are similar to those obtained for black bass, which ranged from $79.3 \%$ to $99.5 \%$ (Anderson, 1974; Flickinger et al., 1975; Kubitza, 1995b). The addition of cod liver oil did not improve the feed intake or the RFB values (74.2\%), opposite to the results obtained for black bass trained with similar diets (Flickinger et al., 1975). The same is true in regard to the use of moisture as feed enhancer in the diets, which did not improve feed intake or the RFB $(70.8 \%)$ when compared to dry diets.

Furthermore, according to Kubitza (1995b) the texture of the training diets also does not affect the percent of black bass feeding on the final dry diet. The same pattern was observed in this work. The weight gain of peacock bass, ranging from 0.1 to $0.17 \mathrm{~g} /$ day, was similar to that obtained for black bass during feed training, when semi-moist pellets were used -0.1 to $0.13 \mathrm{~g} / \mathrm{day}$, but somewhat inferior to that recorded for the flounder (Solea solea) 0.8 to 1.4 g/day (Snow, 1968; Anderson, 1974; Fuchs, 1982a, b; McCraren, 1975; Kubitza, 1995b; Sloane \& Lovshin, 1995; Kubitza \& Lovshin, 1997a).

Under the particular conditions of this experiment, results indicate that ground fish flesh is the best starter diet for feed train peacock bass, and flavor enhancers do not influence significantly success in either peacock bass training or feed transition phases. It is also possible to infer that greater success in producing advanced peacock bass fingerlings can be obtained if fish start feed training process with average initial weight equal to or greater than $1.0 \mathrm{~g}$. Results herein obtained encourage additional studies on the development of feed training strategies for the peacock bass, enabling the commercial farming of the species for both sport and table fish purposes.

Acknowledgments - The authors are indebted to Dr. José Fernando Machado Menten (LPA-ESALQ-USP) for his critical review, suggestions and comments to the manuscript. Financial support was provided by FAPESP (proc. \# 95/09554-9). This paper represents partial data of the first author's MSc Thesis, fellowship awarded by FAPESP (proc. \# 96/02853-3).

\section{REFERENCES}

ANDERSON, R. J., 1974, Feeding artificial diets to smallmouth bass. Progr. Fish Cult., 36(3): 145-151.

BRAGA, R. A., 1982, Crescimento do tucunaré pinima Cichla temensis Humboldt, em cativeiro (Actinopterygii, Cichlidae). pp. 101-109. In: Departamento Nacional de Obras Contra a Seca (ed.), Coletânea de Trabalhos Técnicos do DNOCS. MINTER-DNOCS, Fortaleza, 2 Vol., 418p.

BRANDENBURG, A. M., RAY, M. S. \& ANDERSON, R. J., 1979, Use of carp eggs as a feed for fingerling largemouth bass. Prog. Fish Cult., 41: 97-98.

BRANDT, T. M., JONES Jr., R. M. \& ANDERSON, R. J., 1987, Evaluation of prepared feeds and attractants for largemouth bass fry. Prog. Fish Cult., 49: 198-203.

CARMICHAEL, G. J. \& WILLIAMSON, J. H., 1986, Intensive production of guadalupe bass. Prog. Fish Cult., 48: 133-136.

FLICKINGER, S. A., ANDERSON, R. J. \& PUTTMANN, S. J., 1975, Intensive Culture of Smallmouth Bass. pp. 373-379. In: H. Clepper (ed.), Black bass biology and management. Proceedings of the National Symposium on the Biology and Management of the Centrarchid Basses, Washington. Sport Fishing Institute, Washington.

FUCHS, J., 1982a, Production de juveniles de sole (Solea solea) en conditions intensives. I. Le premier mois d'élevage. Aquaculture, 26: 321-337.

FUCHS, J., 1982b, Production de juveniles de sole (Solea solea) en conditions intensives. II. Techniques de sevrage entre 1 et 3 mois. Aquaculture, 26: 339-358.

HECHT, T. \& PIENNAR, A. G., 1993, A review of cannibalism and its implications in fish larviculture. J. World Aquacult. Soc., 24(2): 246-261.

HOWICK, G. L. \& O’BRIEN, W. J., 1983, Piscivorous feeding behavior of largemouth bass: An experimental analysis. Trans. Am. Fish. Soc., 112: 508-516.

KUBITZA, F., 1995a, Preparo de rações e estratégias de alimentação no cultivo intensivo de peixes carnívoros. pp. 91-115. In: J. E. P. Cyrino \& F. Kubitza (eds.), Anais do Simpósio Internacional Sobre Nutrição de Peixes e Crustáceos do Colégio Brasileiro de Nutrição Animal Campos do Jordão. CBNA, Campinas, 126p.

KUBITZA, F., 1995b, Intensive culture of largemouth bass Micropterus salmoides: Production of advanced juveniles and food-size fish. Ph.D. Dissertation. Department of Fisheries and Allied Aquacultures, Auburn University, AL, USA, 145p.

KUBITZA, F. \& CYRINO, J. E. P., 1997, Feed training strategies for the piscivorous Peacock Bass Cichla sp. p.139. In: A. L. Val, V. M. F. A. Val \& M. N. P. Silva (eds.), International Symposium on Biology of Tropical Fishes. Resumos. Instituto Nacional de Pesquisas da Amazônia, Manaus, 201p. 
KUBITZA, F. \& LOVSHIN, L. L., 1997a, The use of freezedried krill to feed train largemouth bass (Micropterus salmoides): Feeds and training strategies. Aquaculture, 148: $299-312$

KUBITZA, F. \& LOVSHIN, L. L., 1997b, Effects of initial weight and genetic strain on feed training largemouth bass Micropterus salmoides using ground fish flesh and freeze dried krill as starter diets. Aquaculture, 148: 179190

LARSEN, L., 1993, Peacosk Bass Explosions! Larsen's Outdoor Publishing, Lakeland, FL, USA, 192p.

LEWIS, W. M., HEIDINGER, R. \& KONIKOFF, M., 1969, Artificial feeding of yearling and adult largemouth bass. Prog. Fish Cult., 31: 44-46.

LOVELL, R. T., 1989, Nutrition and Feeding of Fish. AVI Book, Van Nostrand Reinhold International Company Ltd., New York, 260p.

LOVSHIN, L. L. \& RUSHING, J. H., 1989, Acceptance by largemouth bass fingerlings of pelleted feeds with a gustatory additive. Prog Fish Cult., 51: 73-78.

McCRAREN, J. P., 1974, Hatchery production of advanced largemouth bass fingerlings. pp. 260-270. In: Proceedings of the Annual Conference of Western Association of State Game and Fish Commissioners LV, Albuquerque, NM, USA.

McCRAREN, J. P., 1975, Feeding young bass. Farm Pond Harvest, 9(3): 10-12.

MOREAU, R. \& DABROWSKI, K., 1996, Feeding stimulants in semipurified diets for juvenile lake sturgeon, Acipenser fulvescens Rafinesque. Aquacult. Res., 27: 953-957.

ONO, E. A., 1996, The influence of genetic selection, starter diet and training duration on the ability of Largemouth bass (Micropterus salmoides) fingerlings to accept feeds. M.Sc. Thesis. Department of Fisheries and Allied Aquacultures, Auburn University, AL, USA, 47p.

PEIXOTO, J. T., 1982, Alimento de Tucunaré Cichla ocellaris (Bloch \& Schneider), no açude Lima Campos, Icó, Ceará (Atctinopterygii, Cichlidae). pp. 161-170. In: Departamento Nacional de Obras Contra a Seca (ed.), Coletânea de Trabalhos Técnicos do DNOCS. MINTERDNOCS, Fortaleza, 2 Vol., 418p.
PERRONE, E. C., BORGES FILHO, O. F., COUTINHO, C. L. \& GALVÃO, R. A. M., 1993, Hábitos alimentares de uma comunidade de peixes do reservatório de Águas Claras, município de Aracruz, ES. p. 165. In: Instituto Oceanográfico da USP (ed.), Anais do X Encontro Brasileiro de Ictiologia. Resumos. IOUSP, São Paulo, 430p.

ROTTIERS, S. V. \& LEMM, C. A., 1985, Movement of underyearling walleyes in response to odor and visual cues. Prog. Fish Cult., 47(1): 34-41.

SAINT-PAUL, U., 1986, Potential for aqualculture of South American freshwater fishes: A review. Aquaculture, 54: 205-240.

SANTOS, E., 1987, Pesca e Piscicultura. 2a ed. Editora Itatiaia, Belo Horizonte, 267p

SLOANE, M. B. \& LOVSHIN, L. L., 1995, Feed training and intensive production of advanced largemouth bass fingerlings: A review. Rev. Fish. Sci., 3(1): 65-89.

SNEDECOR, G. W. \& COCHRAN, W. S., 1989, Statistical Methods. 8a ed., The Iowa State University Press, Ames, IA, USA, 520p.

SNOW, J. R., 1968, Production of six-to eight-inch largemouth bass for special purposes. Prog. Fish Cult., 30: 144-152.

STEEL, R. G. D. \& TORRIE, J. H., 1980, Principles and Procedures of Statistics: A biometrical approach. 2a ed., McGraw-Hill, New York, 631p.

STOREBAKKEN, T., 1998, Krill as a potential feed source for salmonids. Aquaculture, 70: 193-205.

WILLIAMSON, J. H., 1981, Training northern largemouth bass fingerlings on OMP. Prodeedings of The Catfish Farmers American Research Workshop, 3: 68-69.

WILLIS, D. W. \& FLICKINGER, S. A., 1981, Intensive culture of largemouth bass fry. Trans. Am. Fish. Soc., 110: $650-655$.

ZARET, T. M., 1980, Life history and growth relationship of Cichla ocellaris, a predatory south american cichlid. Biotropica, 12(2): 144-157. 